\title{
The TCJA's Reductions of Tax Accounting Compliance Burdens for Small Business Taxpayers
}

\author{
Paul Brennan \\ Minnesota State University Mankato \\ Kirsten Rosacker \\ Minnesota State University, Mankato
}

\begin{abstract}
The Tax Cut and Jobs Act of 2017 (TCJA), signed by Congress and President Trump in December of 2017, is the most significant piece of tax legislation in over 30 years. Every type of taxpayer subject to U.S. Federal income tax law is affected by the noteworthy changes of this Act. The TCJA includes provisions that make substantial changes in tax accounting methods applicable to small business taxpayers. Small businesses employ 59.9 million people, which accounts for 47.3 percent of all employees in the United States (SBA Office of Advocacy, 2019). This paper offers background information regarding tax accounting methods and specifies how the TJCA impacts tax compliance for small businesses.
\end{abstract}

Keywords: Tax Cut and Jobs Act, inventory accounting, small business taxpayers, tax accounting methods, and tax compliance

\section{INTRODUCTION}

The Tax Cut and Jobs Act of 2017 (TCJA) is the most extensive tax overhaul to the U.S tax code since the Tax Reform Act of 1986. This paper focuses on the positive effect of the TCJA to small business taxpayers. Precisely, this paper describes four significant ways in which the TCJA (or merely the Act) simplified tax accounting compliance burdens for small business taxpayers, which compose a large segment of the U.S. economy.

First, the Act expands the definition of "small business" taxpayers to include a substantial majority of U.S. business entities. Second, this Act allows more business taxpayers to use the cash method of accounting. Third, the Act relaxed inventory accounting and capitalization requirements. Finally, the TCJA allows more contractors to use the completed-contract method for their long-term contracts rather than the percentage-of-completion methods of tax accounting. This paper will describe the tax law related to these four items before 2018 and then describe the current state of this area of tax law. 


\section{PART I - BACKGROUND}

\section{Use of the Cash Method}

Taxpayers, under the cash method of accounting, generally must record revenue when related cash or cash equivalents are constructively received; additionally, taxpayers record expenses when payment occurs or constructive payment takes place. While the accrual method of accounting may be superior to the cash method for tying the recognition of revenues and expenses to efforts and obligations of the earnings process, the cash method, with its matching of revenues and expenses to the receipt and payment of cash, more closely matches income to the ability to make the cash tax payments on computed profits. Additionally, the cash method was easier to implement and maintain as it required few, if any, of the estimates inherent in accrual accounting. The ease of implementation was a constructive factor in promoting taxpayer compliance. Historically, the tax law has not featured pure forms of cash or accrual accounting. Traditionally, cash basis taxpayers have been required to use accrual methods for specific items and accrual-based taxpayers have been permitted (or required) to use cash methods under prescribed circumstances.

\section{Accrual Requirement}

Historically, the cash method was not available to certain types of taxpayers, such as C-Corporations, partnerships with one or more C-Corporation partners, and tax-shelters. This general rule eroded over the years. C-Corporations classified as Personal Service Corporations (those engaging in professional services like law, accounting, medicine, architecture, engineering, consulting, or performing arts) were able to use the cash method regardless of entity size. Farming corporations and partnerships with a corporate partner were exempt from the accrual accounting required if average gross receipts for a threeyear-period did not exceed $\$ 1$ million, and family farming corporations were exempt from the accrual requirement if gross receipts were under \$25 million. Congress amended Internal Revenue Code Section (IRC) 448 to allow C-Corporation and partnerships with C-Corporation partners to use the cash method if average annual gross receipts (for a three-year-period) did not exceed $\$ 5$ million.

\section{Inventory}

Business taxpayers with inventories (producers, wholesalers, and retailers) generally were required to use the accrual method for their inventories even when the business taxpayers were not required to use the accrual method for other tax accounting records (IRC 471). Inventory sales were recorded at the time of sale rather than at the time of cash collection. Inventory costs were capitalized as inventory asset accounts and could not be expensed until the sale. The overall result of the accrual requirement for inventory producers and sellers was the delayed expensing of inventory costs while goods remained unsold. The basic tax rules of inventory accounting generally conformed with the principles of financial accounting and cut across all types of taxpayers, not just C-Corporations.

Early in the $21^{\text {st }}$ century, the Internal Revenue Service (IRS) decided to relax the requirement for specific taxpayers to maintain inventories under the traditional accrual method. Businesses with average annual gross receipts (for three years) of $\$ 1$ million or less first were exempted from the accrual inventory requirements (Revenue Procedure 2000-22, Revenue Procedure 2001-10). Those taxpayers could recognize revenues on the cash basis but were required to treat the inventory costs at "non-incidental" materials and supplies where they could deduct the costs of inventories upon the latter of sale or payment for the inventory. Subsequently, the IRS relaxed the standard further for particular taxpayers with average annual gross receipts of up to $\$ 10$ million. These were taxpayers who 1) were not primarily engaged in farming, retailing, wholesaling, publishing, or recording; or 2) primarily service providers who provided some inventory items incidental to services, and; 3) were not C-Corporation. This exemption to the accrual method requirement reduced the inventory accounting burdens on taxpayers like non-corporate, job order contractors. 


\section{Uniform Capitalization Rules}

Although tax laws conformed with the basic accrual principles of financial accounting for inventories, the tax inventory capitalization rules went beyond the normal absorption costing rules of financial reporting requiring only production costs to be capitalized. In 1986, Congress enacted IRC 263A, the Uniform Capitalization Rules (UNICAP), requiring a portion of non-production costs to be capitalized into inventory along with the usual production costs. In addition to production costs, the UNICAP rules required purchasing, handling, storage, and mixed service costs to be allocated to inventories. Specific categories of administrative expenses (e.g., marketing and selling; financial accounting, tax, financial planning, and risk management; internal audit; shareholder relations; and top management) were exempt from capitalization (Treasury Regulation 1.263A-1(e)(iii)).

As initially enacted, the UNICAP rules applied to producers and resellers of real estate or tangible personal property (non-real estate), but various classes of taxpayers were exempted either from the original rules or amendments after the enactment of the UNICAP rules. Producers of trees, animals, crops with a production period of two years or less, and the costs of freelance authors, photographers, and artists were exempt from these rules. Before amendment by the TCJA, resellers (not producers!) of property other than real estate with average annual gross receipts of $\$ 10$ million or less were exempt from the UNICAP rules. Former rules also exempted producers with total indirect costs of $\$ 200,000$, long-term contractors (who were subject to IRC 460), taxpayers in farming, and other specified businesses (Treasury Regulation 1.263A-1(b)).

\section{Long-Term Contractors}

Taxpayers whose production and sale periods could extend beyond one year and whose accounting methods were controlled by IRC 460. These taxpayers had a general inventory capitalization requirement and a general requirement to use one of two primary accounting methods for long-term contractors: the more straightforward completed-contract method and the more complex percentage of completion method. The completed-contract method allowed contractors to defer recognition of revenues and expenses until the completion of the contract. Small contractors (average gross receipts not exceeding $\$ 10$ million) with construction contracts not exceeding two years, homebuilders, and low-density residential contractors (units with four or less dwelling units) were permitted to use the completed-contract method (IRC 460(e)(6)(a)).

Unlike the completed-contact method, the percentage of completion method required contractors to recognize construction profits in each year based on the percentage of completion accomplished in that year. The percentage of completion method required annual estimates of contract completion. Contractors using the percentage of completion method were also subject to a "lookback" rule upon the completion of the contract unless the differences between the previous estimates of the completion percentage and the actual completion percentages in prior years were relatively small (within 10\%). The result of the lookback rule was an interest charge on underpayments of income taxes in prior years based on underestimated completion rates.

\section{PART II - CHANGES TO TAX ACCOUNTING RULES FOR SMALL BUSINESS TAXPAYERS ENACTED BY THE TCJA}

\section{Overview}

The TCJA redefined the small business taxpayer by enlarging the gross receipts threshold to qualify for the less complicated tax accounting methods available to businesses in that class. The TCJA applied a single \$25 million average annual gross receipts threshold to define the small business taxpayer. The new gross receipts threshold replaced the various gross receipts tests that applied to different exemptions from specific accounting methods. In most cases, the tax law exempted businesses under the threshold from having to use the accrual method, from the previous rules for inventory accounting, from having to apply the Uniform Capitalization Rules, and from having to use the percentage of completion method. 


\section{Allowance for Use of the Cash Method by Corporations under the TCJA}

Under the TCJA, C-Corporations and partnerships with a corporate partner may use the cash method if their average annual gross receipts, during a three-year-period, do not exceed \$25 million (\$26 million for 2019). The $\$ 25$ million limit, also replaces the much smaller gross receipts limit that previously applied to farming corporations and to farming partnerships with corporate partners while leaving the same \$25 million gross receipts limitation for family farming corporations. The unlimited allowance to use the cash method applicable to Personal Service Corporations was not changed.

The most recent statistical compilation of $\mathrm{C}$ corporation tax returns published by the IRS was for the 2014 tax year (Internal Revenue Service, 2014). That publication did not include a gross receipts category ending at $\$ 25$ million but included a category ranging from $\$ 10$ million to $\$ 50$ million. If half of the corporations within that range were assumed to fall below the $\$ 25$ million gross receipts limit, an estimated ninety-seven (97) percent of C corporations would have been small business taxpayers in 2014. Furthermore, since Personal Service Corporations could use the cash method regardless of size, a higher percentage of corporations than that estimate would have been able to use the cash method under the new gross receipts rule. The old rule requiring $\mathrm{C}$ corporations to use the accrual method now applies to only a small minority of corporations.

\section{Exemption from the Requirements to Keep Inventories under the Rules of IRC 471}

The TCJA exempted taxpayers (other than tax shelters) from the requirement to keep inventories under the accrual requirements of IRC 471. Those taxpayers falling under the \$25 million gross receipts threshold now have the choice of accounting for inventories in a manner consistent with their Applicable Financial Statements (AFS) or accounting for inventories as non-incidental materials and supplies (IRC Section 471(c)(1)(B)(i) \& (ii)). Taxpayers using the same methods to account for inventories as used in their AFS likely would use a traditional GAAP based accrual method to account for both inventory sales revenue and costs of goods sold. Producers will capitalize acquisition costs of materials, production labor, and production overhead into the costs of manufactured goods.

For taxpayers treating inventories as non-incidental materials and supplies, Treasury Regulation 1.162-3 governs the accounting treatment of materials and supplies. Incidental materials and supplies do not require record keeping and maybe expensed as purchased. The taxpayer must track the inventories of non-incidental materials and supplies, and these may not be deducted until they are consumed or used in the taxpayer's business (Treasury Regulation 1.162-3(a)(1)). For merchandise inventories treated as nonincidental materials and supplies, the IRS interpreted "used and consumed in the taxpayer's business" to mean that the inventory costs should not be deducted until the latter of the time the inventories were sold to customers or the taxpayer paid for the inventories. Small business taxpayers treating merchandise inventories and non-incidental materials and supplies may choose either the cash or accrual method to account for the recognition of sales revenue but may not deduct the cost of inventories before a sale (Revenue Procedure 2002-28).

With the relaxation of both the inventory and Uniform Capitalization requirements, small business producers treating inventories as non-incidental materials and supplies presumably would capitalize only the purchase and acquisition costs of the component materials used in finished products and would not capitalize production labor and production overhead into finished products. A lesser capitalization requirement results in a substantial simplification of inventory accounting for small producers but creates a substantial difference between small producers using the inventory methods of applicable financial statements (AFS) and those producers treating inventories as non-incidental materials and supplies. The latter would have lower inventory cost valuations and earlier expensing of inventory costs.

\section{Exemption from the Uniform Capitalization Rules under the TCJA}

The TCJA exempted corporations and all other taxpayers (other than tax shelters) from the requirement to use the Uniform Capitalization Rules if average annual gross receipts for a three-yearperiod did not exceed \$25 million. Unlike the prior \$10 million exemption that applied only to resellers, the $\$ 25$ million exemption extends to both producers and resellers. 


\section{Exemption from the Percentage of Completion Method Requirement for Long-Term Contractors}

The TCJA expanded the pool of contractors eligible to use the more straightforward completedcontract method. Additionally, the Act replaces $\$ 10$ million average annual gross receipts limitation with the new \$25 million limitation for the small contractor. Small contractors are now those with average annual gross receipts of $\$ 25$ million whose contracts will conclude in two years or less. The previous exemption from the requirement to use the percentage of completion method for home and low-density residential builders remains.

\section{Changing to the Small Business Accounting Methods under TCJA}

The IRS issued Revenue Procedure 2018-40 to clarify the procedures applicable to the many anticipated requests for changes in accounting methods due to the provisions of the TCJA. Changes to the small business accounting methods described above benefit from automatic consent treatment. Under automatic consent procedures, taxpayers pay no fees to change accounting methods, may take IRC 481 adjustments (income differences due to changes in accounting method similar to the cumulative effect on changes in accounting principle of financial accounting) over four years if positive or take the entire income adjustment in the year of change if negative, and have extended time to file the election (the election may be made with the filing of the return for the year of change). Requests for changes to the cash method, changes to the simplified inventory methods, and changes due to the exemption from the Uniform Capitalization Rules involved the IRC 481 adjustments described above. The requests of longterm contractors changing from the percentage of completion method to the completed-contract method required the use of a cut-off method (Clark, 2019). Under a cutoff method, IRC 481 adjustments do not occur. Instead, projects in effect before the change employ the former method and projects initiated after the change use the new accounting method.

\section{QUESTIONS FOR THE FUTURE}

Of the small business tax accounting changes enacted by the TCJA, perhaps the most significant source of compliance uncertainty concerns the implementation of the simplified inventory procedures. The relaxation of previous inventory accounting procedures may invite substantial deviations from longestablished inventory accounting practices. IRC 471(c)(1)(B), as amended by the TCJA, stated that a taxpayer's method of accounting for inventory will be deemed to fairly reflect income if the method:

"(i) treats inventory as non-incidental materials and supplies, or (ii) conforms to such taxpayer's method of accounting reflected in an applicable financial statement (AFS) of the taxpayer with respect to such taxable year or, if the taxpayer does not have any applicable financial statement with respect to such taxable year, the books and records of the taxpayer prepared in accordance with the taxpayer's accounting procedures."

IRC 451(b)(3) describes an Applicable Financial Statement (AFS). An AFS is, in hierarchical order, 1) an audited statement prepared in accordance with generally accepted accounting principles (GAAP) that is used for public company filings, credit purposes, shareholder reporting, or another substantial nontax purpose, or filed with a Federal agency for a non-tax purpose; 2) prepared in accordance with international standards and filed with an international agency, 3) a financial statement filed with a governmental or regulatory agency approved by the Treasury Department. For producers with applicable financial statements, there should be little uncertainty regarding how to account for inventories. Those producers would use the accrual method and capitalize all production costs into manufactured inventories.

For producers without applicable financial statements, treating inventories as non-incidental materials and supplies may or may not require capitalization of anything other than materials incorporated into the finished products. The most nebulous of the alternatives is the allowance for the taxpayer without an applicable financial statement to treat inventories consistent with the "books and records of the taxpayer prepared in accordance with the taxpayer's accounting procedures." 
In a lengthy commentary letter to the IRS (Schneider and Smith, 2018), two leading attorneys urged further guidance from the service to clarify the treatment of inventories under the amended provisions. The authors noted that the statutory and regulatory history of materials and supplies distinguished incidental materials and supplies from non-incidental materials and supplies. Conceivably, a taxpayer without an AFS who expenses inventory type items at the time of payment (a cash method) for the taxpayer's books and records may argue that doing that for tax purposes is under the taxpayer's accounting procedures, but that would be treating those items as incidental materials and supplies, and Congress has not given explicit allowance for that treatment. The IRS has ruled that inventory items treated as non-incidental materials and supplies cannot be deducted until those items are transferred to the customer (Revenue Procedure 2002-28), but that older ruling may be limited by the small business taxpayer's exemptions from both of IRC 471 (for keeping inventories) and IRC 263A (for following the Uniform Capitalization Rules) under the TCJA. Schneider and Smith argued that the deduction for nonincidental materials and supplies should be deferred only until those items, under the original applicable language, are "used or consumed" in the taxpayer's business. Following this wording could lead to the conclusion that a taxpayer could expense components materials and supplies at the time those materials enter the producer's work in process. Another possible alternative is whether those materials and supplies could be expensed outright under the de minimums exceptions under the Treasury Regulation 1.162-3(f) and 1.263(a)-1(f). Under these provisions, per item expenditures up to $\$ 2,500$ (for taxpayers without an applicable financial statement) or up to $\$ 5,000$ (for taxpayers with applicable financial statements) may be expensed outright if the taxpayers follow the same practices for accounting purposes. Finally, Schneider and Smith maintained that, following the non-incidental materials and supplies alternative in conjunction with the exemption from IRC 263A, should lead to the conclusion that all direct labor and overhead would be free from capitalization requirements and deductible as incurred.

Under the requests for public comments under Revenue Procedure 2018-40, the AICPA also weighed in with its suggestions and interpretations (AICPA, 2019). The AICPA stressed the tax practitioner community's need for further IRS guidance to clarify to what extent inventory cost capitalization may be required, or required at all, for small business taxpayers. The AICPA also suggested what may constitute adequate accounting procedures and books and records for small business taxpayers without applicable financial statements (AFS).

\section{CLOSING}

The TCJA greatly simplified accounting compliance burdens for small business taxpayers by its exemptions from traditional inventory accounting and capitalization concepts and rules. The alternative accounting procedures permitted by the TCJA are not always clear; this Act introduced uncertainty and the potential for substantial variation in the way small business taxpayers treat their inventories. Further, IRS guidance is welcome and needed. 


\section{REFERENCES}

AICPA. (2019, July 15). Revenue Procedure 2018-40 - Request for Comments and Impact of Public Law No. 115-97 on Accounting Methods for Small Business Taxpayers (letter). Retrieved from https://www.aicpa.org/content/dam/aicpa/advocacy/tax/downloadabledocuments/20190715comment-letter-small-taxpayer-methods. pdf

Clark, N. (2019, January). Relief for small business tax accounting methods. Journal of Accountancy. Retrieved from https://www. journalofaccountancy. com/issues/2019/jan/small-business-taxaccounting-methods. html.

Internal Revenue Code Section 263A. Capitalization and inclusion in inventory costs of certain expenses. Internal Revenue Code Section 448. Limitation on use of cash method of accounting

Internal Revenue Code Section 460. Special rules for long-term contracts

Internal Revenue Code Section 471. General rule for inventories.

Internal Revenue Service. (2014). Statistics of Income - 2014 - Corporation Income Tax Returns

(Publication 16 (Rev. 6-2019), Catalogue Number 61538P). Washington, D.C. US Department of Treasury.

Revenue Procedure 2000-22, 2000-1 CB 1008.

Revenue Procedure 2001-10, 2001-1 CB 272.

Revenue Procedure 2002-28, 2002-1 CB 815.

Revenue Procedure 2018-40, 2018-34 IRB 320.

Schneider, L. J., \& Smith, P. J. (2018, September 12). Comments with Respect to Revenue Procedure 2018-40 (letter). Retrieved from ipbtax.com/media/news/428_09_12_2018\%20LJSPJS\%20IRS\%20Rev\%20Proc\%202018-40\%20comments. pdf

The Tax Cut and Jobs Act (P.L. 115-97). Act Sec. 13102.

Treasury Regulation. 1.162-3. Materials and supplies.

Treasury Regulation. 1.263A-1. Uniform capitalization of costs. 